\title{
TALK
}

\section{Us Against Them: How the Irish Ruled Jersey City}

Thomas Fleming

Abstract: Historian and novelist Thomas Fleming grew up in Jersey City during the heyday of Mayor Frank Hague, and Fleming's father, Teddy, was a close aide to Hague. In this talk presented at Drew University's Casperson School of Graduate Studies in 2009, Fleming recalled the ethos of Jersey City's Irishdominated political organization.

Many years ago, I was getting an award in Trenton for my efforts to make New Jersey memorable in the American

Revolution. Governor Brendan Byrne was supposed to introduce me. We talked offstage for a while before the program started. Then the Governor strolled out to the microphone and said: "I was going to tell you a lot about this guy but I realized it would be superfluous. The second he opens his mouth, you'll know he's from Jersey City."

Like many things Governor Byrne has said, that was good for a laugh. But at a deeper level it said a lot more. In this case, it summed up a good chunk of my identity. I was from Jersey City in the era of Frank Hague. My father, Teddy Fleming, was one of the Mayor's right-hand men. This 
induced a sense of dislocation in my psyche - a feeling that I didn't really belong to the rest of New Jersey or the United States of America.

It started the day I met Frank Hague for the first time. I was seven years old. My father steered me around a huge puddle and led me toward a big black limousine. We were in the parking lot of Roosevelt Stadium on opening day of the baseball season. A tall man in a derby hat was getting into the car. "Mayor," my father said. "I'd like you meet my son."

I gazed up at the Mayor and held out my small hand. He mashed it into what I was sure was a permanent pulp and glared at me as if he had just caught me scalping box seat tickets. "Your old man is a hell of a guy," he growled.

That was the day my commitment to the Irish side of my hyphen was born. By the age of 10 I was a passionate supporter of the Hague Organization. I had the basic philosophy down cold. Us against Them. Us against the twofaced, penny-pinching Irish-Catholic-hating Protestant 
Republicans in the rest of New Jersey. They were trying to drive us back to the days when being Irish meant you dug ditches and lived on handouts when the jobs ran out. There was nothing the Republicans wouldn't do to us - no trick was too dirty, no lie was too big -- which meant it was perfectly okay to play the same nasty game against them - and do it 10 times better - tougher, smarter.

It didn't bother me in the least when I watched my father in action in Jersey City's Sixth Ward. After one election in the 1930s, which the organization won by the usual 20 to 1 margin, a committeeman stopped by to brag that he had carried his district 998 votes to one. "You idiot!," Teddy Fleming roared. "Don't you know there were two Republican pollwatchers? What happened to the other guy's ballot?"

The committeeman mumbled that the ballot must have gotten soiled. This was a standard way to diminish the already miniscule Republican vote. The counters dropped 
their ballots on the floor of the polling place and -- oops!

Someone stepped on them. Soiled ballots could not be

counted. But there were sensible limits to this game, which

the not-too-bright committeeman had ignored.

Someone leaked the story to the newspapers and it

made headlines in Republican papers around the state. But

nobody in Jersey City batted an eye, much less called for an

investigation. It didn't diminish my father's standing at City

Hall one iota.

Another vivid memory is Reverend Lester Klee's 1937

race for governor on the Republican ticket. He was the

personification of all our Irish fantasies about prejudiced

Republicans. Not only was Klee a quintessential Protestant

but he was a sanctified ordained one, who preached scathing

sermons denouncing Irish-Catholic political corruption. The

election was close enough for Klee to scream it had been

stolen in Jersey City. He got a court order from a judge,

impounding the ballot boxes, and the judge sent a squad of 
state troopers to seize them in the Hudson County Court House in Jersey City.

The state troopers were met by 30 or 40 well-armed Hudson County policemen, each with a face that, as the saying goes, was a map of Ireland. The two groups confronted each other for several hours and the state cops went back to Trenton without the ballots. The chief justice of the state Supreme Court was Thomas Brogan, the former corporation counsel for Jersey City. He ruled there was no evidence of widespread corruption, hence no need to surrender the ballots. The Reverend Klee conceded defeat and Frank Hague once more controlled that vital post, the governorship of New Jersey, with its awesome appointive powers - above all the authority to name each county's prosecutor.

Even on the relatively rare occasions when Frank Hague's man lost a gubernatorial election, there were precautions taken to avert disaster. My father's brother-in- 
law, Al Gallagher, was a quiet, likeable man with a pleasant sense of humor. He worked for the Hudson and Manhattan

Railroad, now known as PATH. Whenever Hague lost control of the prosecutor's office, Uncle Al, as I called him, did not make many appearances at his place of work. He was on one grand jury after another. If there was any discussion of indicting or otherwise pursuing Hague or any other member of the organization, $\mathrm{Al}$ would quietly inform my father, who would swiftly notify City Hall. This was a clear violation of Al's grand jury oath of secrecy. It is worth mentioning that $\mathrm{Al}$ was a daily communicant. But "Us Against Them" gave him a moral exemption from taking his oath too seriously.

It is a vivid - and perhaps sobering - confirmation of the way Irish Americans handled their everyday political and personal lives. Someone has described it as a three-decker mentality. On matters political, their strongest Irish virtue, loyalty, committed them to the Irish politicians who ran the 
government of the city, county or state. On matters religious, such as marriage or abortion, they listened to their religious leaders. On matters having to do with Ireland and its struggles and woes, they listened to men like John Devoy who had devoted their lives to Irish independence. But if any of these authority figures crossed over into the other two bailiwicks and threw their weight around, they were ignored. This explains why every Irish Catholic in Jersey City could read with equanimity the story of Mayor Hague donating \$1 million to Archbishop Thomas Walsh of Newark to embellish his seminary. And why the Archbishop accepted the check with a smile and a warm expression of gratitude. Walsh too was part of the "Us Against Them" mentality and he knew how perilous it would be for the stability of his archdiocese if he suddenly issued a denunciation of the mayor or worse, the Democratic Party of New Jersey. I'm not claiming that the Archbishop literally thought in "Us Against Them" terms. That formulation is the business 
of those who write history and enjoy reading -- and arguing about it with the aid of that marvelous, much-abused virtue, hindsight. But almost every Catholic priest as well as the archbishop liked Frank Hague for the very Irish way he had shut down all the bordellos that made Jersey City locally famous. The Mayor also barred women from the back rooms of saloons, which were the favorite hangouts of streetwalkers. He also insisted on the saloons shutting on time. Remembering what things were like before he arrived, they decided he was probably the best deal they could get and he was one of their own kind.

There are ramifications and subtleties in "Us Against Them" that historians haven't sufficiently explored. Let's take the most obvious one. The idea enabled Frank Hague to unite the Irish of Jersey City into a majority that took over the metropolis. If you think this was not much of an accomplishment, you should spend a few hours reading the city's newspapers around the turn of the $20^{\text {th }}$ Century. The 
Jersey City Irish's ability to quarrel with and betray each during these decades is a virtual paradigm of Dr. Samuel Johnson's great line, “The Irish are a wonderful people. They never speak well of each other."

Frank Hague changed that dirge to a victory bellow with a brilliant combination of bare-knuckled leadership and political shrewdness. Jersey City, I should add, had the second-highest percentage of Irish-Americans in the U.S. a century or so ago. Only Boston's was larger - by a mere tenth of a percent. In both places, it was far from a majority but when it was welded into a bloc vote, it gave Hague the momentum to take control of the city, then the county, and finally, the state.

Control of the state was never absolute, of course. It was a perpetual negotiation. But for the better part of 25 years, Hague and his Irish followers had the sort of power that won national attention. It was no accident that the Mayor became vice chairman of the Democratic National Committee. 
Hague never achieved his greatest ambition -- to

weld all the satellite towns of Hudson County into one

metropolitan entity, Greater Jersey City. Across the Hudson

River in New York, Tammany Hall had managed this feat in

1898. The idea had been proposed by good government

reformers, better known as the goo-goos, who saw it as a way

of outvoting Tammany. But Tammany won the election with

a slogan that was pure Irish-American and perfectly tuned to

the time and place - "To Hell with Reform."

When Hague proposed the unification of Hudson County,

it was ferociously opposed by his Republican enemies in

Trenton. Then came the cataclysm known as the Great

Depression. The Mayor was forced to abandon the vision and spend several years struggling for mere survival.

But this strategic retreat should not diminish the scope of Hague's achievement. The organization he constructed and led was the most-effective political entity created by Irish- 
Americans in the $20^{\text {th }}$ Century. That is a large statement, I know. But I think it can be defended.

The "Us Against Them" concept takes on a new dimension when it is seen from the inside. Hague's leaders knew how good they were at rolling up a massive vote. Contrary to the impression one might get from the story of the two Republican poll watchers' ballots, this feat was not achieved by runaway fraud-- concocting hundreds and even thousands of fake ballots - or importing floaters from New York or Philadelphia.

The Hague Organization's success was achieved by daily, weekly, year-round effort and frequently exhausting attention to the needs and complaints and pleas for help from the voters. Capping this hard work was Hague's insistence that before each election, every living person in Jersey City was asked, face to face, by a district committeeman or committeewoman, to cast his or her vote for the Democratic Party. 
In the late 1930s, when Mayor LaGuardia had Tammany

Hall on the ropes in New York City, I remember my father talking of the fallen champions in condescending, even scathing terms. They had come apart. Nobody trusted anybody - all they had to attract voters was playboy idiots like Jimmy Walker. Then came the ultimate obloquy from my father - “they don't even canvass." In Teddy Fleming's eyes, a political organization that didn't canvass was tantamount to a fraud or a joke.

I hope by now some of you have noticed that I haven't used the phrase "political machine" thus far. It's hardly a major reform, but I think historians of Irish-America should band together to scour the word from their vocabularies. I can't think of a more misleading way to describe an IrishAmerican political organization. The mere word "Irish" should make it clear they were as different from a machine as two ideas or realities can get. 
We are talking about a carefully assembled group of human beings of different ages and temperaments. It is shot through with those typical human failings, envy and greed, and thick with personal ambitions and hopes and being Irish, with spasms of rage. Such a creature can only be controlled by strong leadership, from the top down, with similar leadership exercised by ward leaders like my father.

How did they do it? By staying on the job, 52 weeks a year. Every day except Sunday, when the saloons were closed, my father spent his nights in the Sixth Ward, first seeing people in the ward clubhouse for two or three hours, then moving from saloon to saloon, listening to tall tales, groans of misery, pleas for help. Always with a glass in his hand, but never getting drunk.

In the late thirties, Teddy Fleming bought a summer house in Point Pleasant. He never spent more than a two-day weekend there. He knew how envy would fester if people asked where Teddy Fleming was and they were told he was 
on vacation in Point Pleasant - while they sweated through the dog days of July and August on the Jersey City's baking streets.

In his old age, when I was on my way to becoming an American historian, I remember trying to tell him what I thought he had accomplished. In speeches he used to tell them, "You are my people. Never forget that." He had created committees of Italians, Poles, Czechs, Slovaks and blacks to help him keep in touch with their groups. Thanks to him, there was a sense of community in the Sixth Ward, something painfully missing in our cities today. He looked at me like I was losing my mind once and for all. When I was getting high marks in St. Peter's Prep, he frequently cautioned me about being too smart for my own good.

"Maybe that's all true," Teddy said. "But Tom -- you had to listen to an awful lot of bullshit."

Is that an Irish-American judgment on the voice of the common man? Maybe. But it's also that Irish trait of telling it 
like it is, at least among those you can trust. Teddy Fleming had no illusions about the people he was trying to help. One winter night during the 1930s, he came home for dinner and put a .32-caliber revolver on the kitchen table, as my mother served the main course. She shrieked and my brother and I recoiled.

“Don't sorry, it's not loaded," he said. He dug a hand in his pocket and showed us the six bullets. He told us he had just acquired the gun from a Polish-American in the ward clubhouse. "How?" I asked.

"When he got to the head of the line, he had a funny look on his face. He asked me for a job, like everyone else. I realized it was the second or third time I'd seen him. I told him to go down to the docks in Hoboken and gave him the name of a guy who'd be running a shape-up over there. He'd give him a job for a couple of days, at least." 
"That's when the guy took out the gun and put it on my desk. 'If you say no job again, I was going to shoot you,"” he said.

"What are you going to do with it?" my brother asked. “I'm gonna put it in my desk drawer, loaded. If anyone else pulls a gun, I'm goin' down fightin'."

Teddy Fleming had seen a lot of combat in France at St. Mihiel and in the Argonne during World War I He wasn't fazed by the possibility of getting killed in a shootout. But being Irish, he was going to shoot back.

A story like that may help you understand why Hague's leaders were proud of the job they did. They weren't a bunch of Tony Soprano type lugs, lurking on the fringes of respectability. They considered themselves professionals in politics and equally good at running a city. And they were very good. While other cities writhed in Mafia shootouts and John Dillinger-like crime waves, the mostly Irish police force kept Jersey City virtually crime free. 
Thanks to Hague the filthy water that people drank at the turn of the century was replaced by pure water from professionally maintained reservoirs. He didn't do any of this by padding the city payrolls in all directions. Recent studies suggest he was a tightfisted, rather frugal administrator.

I saw another side of "Us Against Them" one night at the Jersey shore in the 1940s. I was a typical self-absorbed adolescent who wanted to be a basketball star. I realized I wasn't going to achieve that dream at St. Peter's Prep in Jersey City. The competition was too good. But guys I hung around with in Point Pleasant thought I had a great hook shot and urged me to consider enrolling in a school down there for my junior and senior high school years. I obliquely and cautiously broached the idea to my father along the following lines. 
"Did you ever think of going into politics here?" I asked.

"With your experience I bet you could wind up running all of Ocean County."

Teddy looked up and down our quiet tree-lined street.

"You could take over the whole thing for maybe thirty

grand," he said. "But what would you have when you got it?

Nothing but a bunch of hayseeds."

That was a glimpse of another important angle to Irish political power in New Jersey. They were all city guys who looked with disdain on the unsophisticated naïve ways of life and thought in the state's small towns.

I got another glimpse of this side of Teddy Fleming's life when I gave him a book to read in his retirement years. The title was "Great Criminals of Our Time." I came back for another visit a few days later and asked him what he thought of it. "What a phony book," he said. "I never met one of those guys." 
There was another reason for the Irish success in New

Jersey's politics in the first half of the $20^{\text {th }}$ Century. They

never broke their word. A promise once made was a contract

that had to be fulfilled, no matter how many headaches went

with trying to deliver on it. What made a promise binding in

that unbreakable way was a handshake.

This first dawned on me one summer day when a

Jersey City man approached my father outside church in

Point Pleasant. They stepped aside and talked intensely for a few minutes. The man checked his watch and said he had to leave. He held out his hand and muttered something about a date in the city. My father started to reach for his hand, and then stepped back. "Okay. We'll talk again," he said. The man looked downcast as he walked away.

On the way home I asked my father why he hadn't shaken hands. "He wants a job with the Internal Revenue Service. I'm not sure I can deliver for him. If I shook, I'd go crazy trying to figure out how to pull it off." 
Many a day, my father went down to City Hall for an appointment with Frank Hague. He would ask him to promote one of his Sixth Ward voters to police or fire lieutenant or maybe captain. Sometimes Hague would say no. Someone else was in line for the job. Teddy Fleming frequently refused to take no for an answer. In five or 10 minutes he and the mayor were bellowing insults at each other. More often than not, Hague would finally say: "Okay. But this is the last time!" He would hold out his hand. My father would go to the nearest phone in City Hall and tell his guy he had the job.

Much later, I was told that the Mayor often marveled at my father's nerve. Not many ward leaders talked back to him. "That Teddy Fleming," the Mayor would growl. "He's one in a barrel."

What lay in deeper background behind this political phenomenon, the Hague Organization? Was it all greed and raw ambition? I knew the answer to that one, early in my life. 
My grandfather, David Fleming, was a bull of a man, with massive shoulders and glaring eyes. He looked as if it would not take much to make him explode. I slowly realized why. He was illiterate. He was never able to hold more than a laborer's job. My father's sister, with whom he lived, filled me in on the bitter poverty of her - and my father's -childhood. David Fleming was laid off again and again the moment a building was finished or a sewer dug. They frequently ate on credit from the neighborhood German butcher. They lived in a tenement with no running water and no toilets, except three or four in the back yard. My grandmother, Dave's wife, had to lug water up four flights of stairs several times a day. She strained her heart and died young.

Yet Old Davey, as I called him, had this fierce pride in being Irish. He often paid me a nickel to recite a poem entitled: "Why I Named You Patrick." The last lines go something this: 
And when you see the shamrock son

Be proud of your Irish name

No other one I know of

Can stand for greater fame.

Davey had been born into an Ireland ravaged by the

Famine of the 1840s, which killed a million and a half people, while the English got fat on Irish exports of beef and wheat. He was a very angry man. The mere word "English" raised his blood pressure at least 10 points. In New Jersey and the rest of America, he saw a replay of that atrocity. The rich had mostly English names and they treated the Irish and other immigrants with the same arrogance. Twenty-five percent of Jersey City was owned by the railroads - and thanks to a waiver from the Republican-controlled legislature, they paid no taxes to the city and practically none to the state.

I was too young to have a serious conversation with David Fleming before he died - but I wouldn't be surprised if he 
knew that the state chairman of the Republican Party had his office in the Pennsylvania Railroad building in Trenton.

Make no mistake about it. Irish anger fueled a lot of the energy of the Hague Organization. I glimpsed it the day my father got an agitated call from his sister, telling him that Davey Fleming was in trouble. One of the meanest, mostcontemptible scandals of the day was the revelation that big insurance companies like Metropolitan Life had been collecting premiums from poor people long after the policies had been paid up. Like many Irish, Davey Fleming had paid 25 or 50 cents a month on a $\$ 300$ policy that would give him a decent funeral. When he found out that he had paid it up two or three times, his rage was titanic.

My father's sister - my Aunt Mae - decided it was prudent to meet the insurance man on the street and pay him what was due on policies for her and her husband. 
One day, the insurance man turned up on a different schedule. Mae was not home. Davey answered the knock on the door. "Met Life," chirped the visitor.

Kapow! Davey knocked him down two flights of stairs. Miraculously, the victim was not seriously injured and my father managed to calm him down with enough money under the table to forget the whole thing. Davey stayed out of jail.

The angry side of "Us Against Them" should not be discounted. It could erupt in very inconvenient ways, sometimes beyond the control of Irish-American leaders. In the 1920 presidential election, it almost destroyed the Democratic Party. Irish-Americans had become totally disillusioned with Woodrow Wilson. In 1917, he accused ethnic Americans of "pouring poison in the veins of our national life" -- a remark the Irish took personally. Next, he refused to say a word in favor of Ireland's struggle for independence. He claimed the bloody war between the Irish 
Republican Army and the British army was an internal

British problem.

On November 2, 1920, the Irish voted with their feet.

They stayed home. The Republican presidential ticket

steamrollered through all parts of the nation. They won a

staggering 61 percent of the popular vote. They even carried

New York City by a hitherto unthinkable 440,000 votes when Tammany Hall sat on its hands.

In New Jersey, a desperate Frank Hague watched every

Democratic candidate in sight crumbling before his eyes. He did the only sensible thing: he went all-out to elect the sheriff of Hudson County, the man who controlled the selection of grand juries.

The candidate was an old Hague pal, Thomas "Skidder" Madigan, who had a disability that might have troubled some non-Irish voters: Like Davey Fleming, the Skidder could not read or write. His campaign slogan was even more unusual: "He was good to his mother." Abandoning all other 
candidates, the Hague organization elected the Skidder with a majority that was 100 -percent stolen.

Twenty nine years later, an aging Frank Hague's power in Jersey City and New Jersey was shattered by a revolt inside the Democratic organization. There are lots of reasons why this happened. Underlying them all was the demise of "Us Against Them." Throughout the 1940s, it had been slowly disintegrating under the impact of several major changes among the Irish-Americans and other Americans. My generation, those who experienced World War II, were witnesses and participants in this transformation.

I served in the U.S. Navy, aboard a light cruiser in the Pacific. It soon became apparent to me that being Irish was irrelevant. I had Jewish, Italian and WASP friends. My only sense of Irishness was the way they laughed at my Jersey City accent, with its inability to pronounce the letter "r." They would sit around the give me words to pronounce, such as mother, and roar with laughter when I said "mothuh." 
Back home, another phenomenon transformed the big city wise guys vs. the hayseeds side of "Us Against Them."

Almost everyone my age moved to the suburbs. Another factor was education. The Hague Organization can be viewed as a mass movement of the Irish-Americans into the middle class. The American side of their hyphen prompted parents to send their sons and daughters to college. That experience opened corporate doors and made a political career, with its endless election day uncertainties, much less appealing.

Significant too was the tendency of not a few Irish politicians to tell their sons not to go into politics. I remember Frank Eggers, Mayor Hague's nephew and briefly his successor, saying to me: "I hope you're not going into politics. I've told my son Frank if he does, I'll hit him on the head with something heavy."

It didn't take a lot of brains to realize "Us Against Them" was no longer a winning ticket. After World War II, 
Italians, Poles, Jews and blacks stopped taking orders from the Irish. I didn't know what to do about it. I watched one or two of my Jersey City friends go to jail trying to imitate Hague-style politics. I wrote an article about Jersey City in the Saturday Evening Post, calling it a "city in the shadow" the shadow cast by Frank Hague.

Meanwhile I was deepening the other side of my hyphen, trying to solve that sense of dislocation I mentioned earlier by finding out what that contentious word "American" really meant. I wrote several well-received books about the American Revolution. This process reached a sort of climax in 1970 when I flew to Independence Missouri and met exPresident Harry S. Truman. After reading my biography of Thomas Jefferson, he had selected me to write a book about him in collaboration with his daughter, Margaret.

On my first night in Independence, the president poured me a dark bourbon and water and fixed one for himself and his wife Bess, and one for Margaret. "Young man," Truman 
said, with a somewhat guarded smile. "There's only one thing I don't know about you. Have you always been a Democrat?"

"Mr. President," I said. "My father was leader of the Sixth Ward in Frank Hague's Jersey City. No one in the family has ever voted anything but the straight ticket."

“That's what I wanted to hear!” Mr. Truman said. Mrs. Truman, who was a politician every bit as committed as the president, was even more pleased. Several times during the next few weeks, she looked and me and said: "Tom - you never voted anything but the straight ticket. I like that!"

I thought I was about to enjoy a sort of resurrection of Jersey City days. Here was a man who had come out of the Kansas City Pendergast Organization. But I soon discovered I was wrong. Harry Truman had moved beyond "Us Against Them" politics. Not only the kind that Pendergast practiced, which was often closer to the Mafia variety, but another kind 
that had left terrible scars on our national soul. Truman's mother was an unreconstructed Confederate. One day not long before World War I, he wore his blue National Guard uniform home from a training session. "Harry," Momma Truman said. "This is the last time I want to see that uniform in this house."

In 1946, President Truman heard about honorably discharged black veterans getting beaten up in Mississippi and Alabama when they came home wearing their uniforms. He told his White House staff that wasn't going to happen in the United States while he was in the White House.

In 1948, he proposed a civil rights program that was so tough, the aptly named Dixicrats walked out of the Democratic Convention. Someone asked Strom Thurmond why he was so upset. Franklin Roosevelt had been saying the same things when he was in the White House. "I know that," Thurmond said. "But Truman means it." 
How did Harry Truman do it? He never went near a college. I found out in those weeks in Independence. He did it by reading history. By getting a perspective on what America -- and the rest of the world - was all about. I decided then and there to do the same thing.

That enabled me to appreciate - and applaud -- a lot of things that had changed and were changing in New Jersey. In the suburbs and smaller cities, Irish-American politicians had emerged with no inclination to stay in Frank Hague's shadow. Governor Richard Hughes was the first of these leaders to prove he could think and act and lead on behalf of all the people in the state. Brendan Byrne proved it again, with that marvelous ingredient we Jersey City guys used to admire more than anything else in a politician -- nerve. That's what it took to pass an income tax in a state that didn't pay any taxes worth mentioning in the first century of its existence and paid as little as possible thereafter. 
Now, a young mayor in Newark, Cory Booker, thinks it's time to start leading black Americans with fresh ideas and new vision. Even in Hudson County, where ethnic and racial politics sometimes still resembles a crowded squirrel cage, Senator Robert Menendez has proven that an ethnic American can appeal to the whole state.

Meanwhile, I was getting a perspective on Frank Hague and my father and their generation that enabled me to see them in an honest light -- without denying their flaws. This process reached a sort of climax in a novel I wrote, Rulers of the City, about an Irish-American city in the grip of a school busing crisis.

The book was based very loosely on Boston's experience. I sent a copy to Mayor Kevin White. When I flew to Beantown to promote it, I was met at the plane by the Mayor's car, and taken to City Hall, where White told me it was the best political novel he had ever read. "Can I quote you on that, Your Honor?" I asked. 
"Of course not," the Mayor replied, which did not surprise

me in the least.

In my head I was in Jersey City while I wrote that book.

The mayor was the son of a ward leader from the old "Us Against Them" regime. He was married to a WASP princess who was a fierce liberal. The mayor instinctively sided with the Irish and other ethnics who were screaming race hatred in the streets, even though he knew in his head they were wrong. Meanwhile his wife was making overtures to blacks that seemed more than a little fatal to his future political career.

As things went from bad to worse in the city, the Mayor's marriage headed in the same direction. One explosive day the city's first couple exchanged all the ethnic insults and doubts they had occasionally thought about each other and hastily suppressed.

That night, the mayor felt like he was in danger of falling off the edge of the world. On impulse, he went to a filing 
cabinet and got out all his father's papers. Thomas Fleming, the Irish-American novelist and historian, did the same thing in real time, in his apartment in New York City. He was in a hell of a quandary. He did not know how to end this book.

The mayor -- and the novelist -- sat there reading letter after letter his father had gotten from people in his ward, thanking him for getting a brother out of jail or a son onto the cops or a grandfather into the city hospital. Most of the time the spelling and grammar were atrocious. But the sincerity was totally genuine. These people were deeply profoundly grateful that Teddy Fleming was there and he cared about them and the problems of their small lives.

At aout four in the morning, the mayor realized he'd figured something out. He understood what was happening in his head and in his gut and in his marriage. The old order was gone. Gone and well gone. There was no reason to regret its passing. It had been great while it lasted but it didn't travel into the future. It was time to stop playing the 
self-pity game, time to say goodbye once and for all to the old ways -- the handshake and the handout and the okay from City Hall. How are ya Judge? How much Sheriff? Ireland invoked like an incantation that forgave everything and explained nothing. The Organization and the Church devouring the souls of so many bright young men and women. Time to say goodbye to that world, where all the answers were written in advance in the Baltimore Catechism and the Okay from City Hall. You're well rid of it, Your Honor. Scour from your soul the last iota of regret for its passing.

In his New York apartment, novelist Thomas Fleming was writing those words and simultaneously living them. Tears were pouring down his cheeks. It was a kind of apotheosis that he was sharing with this imaginary mayor who was part him and part a person he would never be, a man of action in the hardball political world. 
Okay, the mayor said to himself. Where did that leave him? What did he have left? Was there anything from the Old Days that you've got in your head and in your gut and is worth preserving? The answer hit him between the eyes. It was their caring. You could take that with you and thank them for it, no matter what happened next.

The Old Crowd didn't care all the time, of course. They were smart enough to look out for number one now and then. But it was there, at the heart of the whole organization. They were trying to help people get through their often messy lives. That was the thing worth remembering. The whole enterprise was a huge struggle to help everyone - Italians, Poles, blacks as well as Irish -- escape centuries of humiliation and defeat and degradation.

The mayor put away his father's papers and called his wife to apologize for the names he had called her. She replied she was about to do the same thing, for her own reasons. 
Together they vowed to bring their fractured city together again.

Caring. That's the central heritage of the Irish-American politicians -- in New Jersey and elsewhere. Ultimately it involved caring about- which means accepting-- all the people in this complicated country, the United States of America. It's a heritage New Jersey's Irish-Americans can look back on with pride. At the ballot box and in the classroom and in the books they may write, future generations can and should use this memory to help others extend its meaning to all Americans in decades to come. 